UDC 81'32: 81'33: 81-116 (811.161.2)

https://doi.org/10.31548/philolog2020.04.083

\title{
STRUCTURE OF SIMPLIFIED MONOMIALS IN UKRAINIAN FOR AUDIT AND ACCOUNTING
}

\author{
O. I. CHAIKA, PhD in Philology, Associate Professor, \\ National University of Life and Environmental Sciences of Ukraine \\ E-mail: oxana.chaika@yahoo.es \\ https://orcid.org/0000-0002-4317-9456
}

\begin{abstract}
The present paper is work in progress and closely relates to the earlier introduced idea of monomials and polynomials as substitutes of the term in linguistics when applicable to terminologies. The term of monomial is seen with the following features. Firstly, it refers to specialised terms, which are natural to one domain only. Secondly, a monomial can be either one-word term or two-word term, or three-word and multi-word term as required in a relevant terminology. According to the complexity of the monomial structure, monomials break into simple (one-term terms), simplified (bi-term monomials), compound and complex. The two latter refer to three-term and multi-term monomials that include the core term (the head of the term cluster) and modifiers (dependents), on the one hand, and on the other, the complex monomial at least reflects a two-tier syntactic hierarchical subordinate relations between the core and the modifier. This paper focuses on the simplified monomials that consist of two notional terms only, hence the name, as opposed to mono-term monomials, or one-word terms simple by nature (ways of term coinage). The material of the study is made with the examples of monomials from the Handbook of International Quality Control, Auditing, Review, Other Assurance, and Related Services Pronouncements as translated into Ukrainian (official wording when published and distributed by the Audit Chamber of Ukraine). The Ukrainian monomials in the field of audit and accounting demonstrate a clear distinction between the two major groups of their coinage and structure. One group speaks of the compound nounal nature as the morphological class of the constituent terms is a noun. The other group of simplified monomials in Ukrainian for Audit and Accounting doubles the number of the aforementioned and is represented by the morphological pattern of adj. $+n$ in most cases under study.
\end{abstract}

Keywords: monomial, simplified monomial, polynomial, terminology, Ukrainian for Audit and Accounting.

Introduction and literature review. The present research links to the previous publication of the findings described in Monomial Variables in English Audit Terminology (2019), Binomials in English Audit Terminology (2019), Monomials in English for Law (2020) and Structure of English Business Monomials (2019), in particular [2;3;4;5]. The underlying concept remains unchanged as introduces the feasible idea of a monomial substitute for the term when dealing with relevant terminologies. The monomial to substitute the conventional 'term' in linguistics appears especially relevant to discuss twoterm, three-term and multi-term terms as opposed to one-term term in terminologies [2; $6]$. For the clarity of the idea, the term stands for a term component / notional word in the term structure. The research connects to the similarity between term expressions in terminologies and algebraic expressions in linguistics. Thus, term expressions as well as mono-terms are referred to as monomials under the research. According to their structure, monomials are divided into simple monomials, simplified, compound and complex.

Simple monomials mean terms that are characterized by one term only in the term structure, and called mono-term monomials, or mono-terms, under the research. Following Chernovaty and Karaban (2004) and in accordance with the classification of terms by the degree of specialization, such mono-term monomials can be expressed [7]:

- By common use words, which may become terms in a specific context, e.g. [topic] shifting in communication strategies;

- General science terms, which may be used in any field of science, e.g. head medicine, physiology, law, business, etc.;

Interdisciplinary terms, which may be characteristic of two or more domains of specialized knowledge, e.g. assessment pedagogy, instruction and training, law, human resources, etc.;

- Specialized terms, which are natural to one domain only, e.g. the Assassins.

Next, two-term monomials, three-term and multi-term monomials break into simplified, compound and complex term clusters as 
opposed to the mono-term. Two-term monomials are seen as a term expression in which terms (notional words) engage in a certain interdependence to convey a meaning / concept of such a monomial. The nature of the said interdependence turns simple in most cases, which is why such two-term monomials fall under the group of simplified monomials. The remainder underpins a more complex nature. Largely, the matter is about either a morphologically and syntactically bound string as a term cluster, or syntactic two-tier or threetier relations. Thus, reading Gerald Kowalski, it becomes obvious that clustering fits well in Information Retrieval for a number of reasons. Clustering can support the search functions for data collection purposes and a proper display of results. However, as the researcher notably underlines "clustering can quickly become computationally impossible and many systems limit the number of items that can be clustered" taken the vast canvases of information data [9].

Further, it should be noted that Richard Rohwer and Dayne Freitag (2004) also refer to similar strings (term clusters under the present research) and aim at "developing methods for automatically constructing a lexicon using only statistical data derived from analysis of corpora" $[11,9]$. The scholars call such a problem lexical optimization and employ statistical methods to receive the information that is equivalent to syntactic categories, on the one hand, and on the other, to work with semantically meaningful text units, which may be multi-word units similarly to our case or polysemous terms in a specific context. The outcome of the mentioned research is the obtained technique of "information theoretic coclustering", which enables to demonstrate the main constituents of lexical optimization, according to the authors $[11,10]$.

Given the above, this paper looks at the simplified monomials in Ukrainian for Audit and Accounting as set term clusters in an $A \& A$ terminology following the earlier presentation of the approach [6].

Aim of the research. The work aims at a set population of simplified monomials in Ukrainian for Audit and Accounting (Ukrainian for $A \& A)$ and analysis of their structure, respectively. Thus, the two objectives set the following tasks:

(a) To sample two-term monomials in Ukrainian for A\&A from the below mentioned material,

(b) To give a definition to the two-term monomial, or bi-term, in Ukrainian for $A \& A$,

(c) To classify two-term monomials in
Ukrainian for A\&A according to the morphological class of the terms in the structure,

(d) To trace a growing frequency range of monomial coinage associated with respective morphological classes of constituent terms.

The simplified monomials from the Handbook of International Quality Control, Auditing, Review, Other Assurance, and Related Services Pronouncements (Volume I) validated by the International Auditing and Assurance Standards Board (IAASB) and translated into Ukrainian as validated by the Audit Chamber of Ukraine make material for the study. The methods applied are use of the Ukrainian language corpora and internet resources, linguistic field research connected with data collection and grammar-oriented component analysis, distributive method followed by the descriptive method.

Discussion and results. The study material is composed from the monomials, i.e. mono-terms, bi-term and multi-term monomials, sampled with the help of Glossary in the Handbook of International Quality Control, Auditing, Review, Other Assurance, and Related Services Pronouncements (Volume I) as officially translated into Ukrainian for professional accountants. It should be noted that only two-term monomials in Ukrainian for A\&A are under focus of the present paper and these are referred to as bi-term monomials, or bi-terms.

Therefore, $a(n)[A \& A]$ bi-term monomial, or bi-term, is a term cluster, which is likely to be used in only one domain of specialized knowledge, e.g. Ukrainian for Audit and Accounting, and consists of two terms (notional words) in its structure. Given simple syntactical relations between such terms in it, an $A \& A$ biterm in the Ukrainian language is called simplified as opposed to other A\&A three-term or multi-term monomials, which compound structure is characterized by a more complex nature, hence the simplified monomial for the former. For instance,

UA базовий рік (bazovyj rik) and its English equivalent base year 'a specific year or an average over multiple years against which an entity's emissions are compared over time' [IAASB, 15],

UA екологічний ризик (ekolohichnyj ryzyk) and EN environmental risk in certain circumstances, factors relevant to the assessment of inherent risk for the development of the overall audit plan may include the risk of material misstatement of the financial statements due to environmental matters' [IAASB, 20], 
Are examples of regular bi-term monomials in Ukrainian for A\&A.

Moreover, the above examples partially or fully coincide in their term syntactical nature given the morphological class of the terms in the monomial structure in two languages. Thus, in Ukrainian and English in the first instance the core term of the two-term monomial is expressed by a noun - UA pik (rik) and EN year, and the modifier is expressed by an adjective базовий (bazovyj) in the Ukrainian language and a noun modifier in preposition in the English language, respectively.

The other instance speaks of the absolute match in Ukrainian and English as the two core terms are expressed by nouns UA ризик (ryzyk) and EN risk, and the modifiers in preposition to the core term are adjectives formed by means of suffixation from the stem in relevant languages: UA еколог-ія (ekolohija) $\rightarrow$ еколог-ічн-ий (ekolohičnyj) and EN environment $\rightarrow$ environment-al.

The samplings of 265 monomials and polynomials in Ukrainian for A\&A help analyse and determine the two major groups of simplified monomials of nominal nature.

Consequently, one group is mainly characterized by the morphological class of the noun, in which the core term in the simplified monomial is expressed by a noun, and its modifier in post-position in the Ukrainian language is also expressed by a noun, for example: UA обсяг огляду (obsjah ohljadu) 'scope of a review' [IAASB, 36], UA процедури огляду (procedury ohljadu) 'review procedures' [IAASB, 35], etc.

The other group of simplified monomials in Ukrainian for A\&A is composed of the nominal term clusters, in which the core term is also expressed by a noun but a modifier may vary in class, from an adjective to present and past participle(s), or an adjectivised noun, where the latter is hardly common of the Ukrainian language. At the same time, this group enlists simplified monomials that double in number the simplified monomials of the afore-mentioned group. For the frequency usage of the morphological nature and syntactical pattern, this group is referred to as Group 1 and the group represented by a compound nounal nature is referred to as Group 2, correspondingly.

Let us give a closer look at these two major groups of simplified monomials in Ukrainian for A\&A.

Thus, Group 1 of simplified monomials in Ukrainian for A\&A includes bi-terms, which subsequently break into six nominal groups under the below described patterns:

1) Adj. + N (in singular): UA аудиторська документація (audytors'ka dokumentacija) 'audit documentation', UA аудиторська фрірма (audytors'ka firma) 'audit firm', UA аудиторський ризик (audytors'kyj ryzyk) 'audit risk', UA аудиторський фрайл (audytors'kyj fail) 'audit file', UA відповідальна сторона (vidpovidal'na storona) 'responsible party', UА державний сектор (derzhavnyj sektor) 'public sector', etc. [IAASB];

2) Adj. + N (in plural): UA відповідні показники (vidpovidni pokaznyky) 'corresponding figures', UA бухгалтерські записи (bukhhalters'ki zapysy) 'accounting records', UA аудuторські докази (audytors'ki dokazy) 'audit evidence', UA аналітичні процедури (analityčni procedury) 'analytical procedures', etc. [IAASB];

3) Past participle + N: UA придбана квота (prydbana kvota) 'purchased offset', UA пов'язана сторона (povjazana storona) 'related party', UA обгрунтована впевненість (obgruntovana vpevnenist') 'reasonable assurance', UA обмежена впевненість (obmezhena vpevnenist') 'limited assurance', etc. [IAASB];

4) Present participle $+\mathrm{N}$ : UA пояснювальний параграфр (ројаsnjuval'nyj parahraf) 'emphasis of Matter paragraph', UA практикуючий фрахівець (praktykujucyj fakhivets) 'practitioner', etc. [IAASB];

5) Pronoun + N: UA інша інфрормація (inša informacija) 'other information' [IAASB];

6) Adjectivised noun + N: UA бізнес-ризик (biznes ryzyk) 'business risk' [IAASB].

As demonstrated above, the simplified monomials in Ukrainian for A\&A consist of two terms that are conceptually and syntactically related and the term in pre-position to the core term in the Ukrainian language is dependent of such core term.

Next, Group 2 includes four sub-groups, among which the compound noun sub-group is the largest in Ukrainian for $A \& A$, in particular:

1) $N+N$ (in singular): UA ayдum групи (audyt Hrupy) 'Group audit', UA aydumop компонента (audytor komponenta) 'component auditor', UA аудumop користувача (auditor korystuvača) 'user auditor', UА викривлення фракту (vykryvlennja faktu) 'misstatement of fact', UA відсутність відповіді (vidsutnist' vidpovidi) 'non-response', UA dama зsimy (data zvitu) 'date of report', etc. [IAASB];

2) $\mathrm{N}+\mathrm{N}$ (in plural): UA межі організації (meži orhanizaciii) 'organizational boundary', UA заходи контролю (zakhody kontrolju) 'control activities', UA обставини завдання (obstavyny zavdannja) 'engagement circumstances', UA 
процедури огляду (procedury ohljadu) 'review procedures', etc. [IAASB];

3) $\mathrm{N}+$ prep. + N: UA завдання з огляду (zavdannja $z$ ohljadu) 'review engagement', UA документація із завдання (dokumentacija $z$ zavdannja) 'engagement documentation', UA команда із завдання (komanda $z$ zavdannja) 'engagement team', UA партнер із завдання (partner iz zavdannja) 'engagement partner', etc. [IAASB];

4) $\mathrm{N}+\mathrm{N}$ (hyphened): UA ruсm-угода (lyst-uhoda) 'engagement letter' [IAASB].

The above examples in connection to Group 2 clearly demonstrate the grammatical structure of the nounal morphological class for the terms in the structure of simplified monomials in Ukrainian for A\&A.

The findings related to Group 2 result in the four to five sub-groups of Ukrainian simplified monomials in the area of audit and accounting. Firstly, the core terms of the simplified monomials are expressed by the noun as a grammatical category. Secondly, the core terms of simplified monomials in Ukrainian for A\&A are modified by another noun in post-position to such core terms. Thirdly, the core terms may be expressed by a plural noun and the nounal modifier may be in plural. Fourthly, government as a syntactic relation between the core term and the modifier (the head and its dependent) turns natural of the Ukrainian simplified monomials in the area of audit and

\section{References}

1. Bolondi, G., Ferretti, F., Maffia, A. (2018). Monomials and polynomials: the long march towards a definition. Teaching Mathematics and Its Applications (2018) 00, 1-12, 2018.

2. Chaika, O. (2019). Monomial Variables in English Audit Terminology, International Journal of Philology, Vol. 10, no 1, Kyiv: «MILENIUM», pp. 100-108. DOI: http://dx.doi.org/10.31548/ philolog2019.01.100

3. Chaika, O. (2019). Binomials in English Audit Terminology. International Journal of Philology, Vol. 10, no 3, Kyiv: «MILENIUM», pp. 68-73. DOI: http://dx.doi.org/10.31548/ philolog2019.03.068

4. Chaika, O., Zakatei, Yu. (2019). Monomials in English for Law, Philological journal, Vol. 2 (14), pp. 114-121. https://library.udpu.edu.ua/library_files/filologich niy-chacopys/2019/2/17.pdf

5. Chaika, O., Bambura, A. (2019). Structure of English Business Monomials, Linguistic Bulletin, no 27, Cherkasy, pp. 69-76 (in Ukrainain). https://www.researchgate. net/publication/339174579 accounting. The use of prepositions in the structure of certain simplified monomials in Ukrainian for A\&A helps broaden the scope of monomial concept inter alia.

Conclusion. The findings of the research illustrate a huge variability of Ukrainian simplified monomials as set bi-term clusters in the audit and accounting domain of knowledge. The Ukrainian A\&A simplified monomials fall under two major groups that distinguish the attributive role of adjectival and nounal modifying terms in the structure of the simplified monomial. According to the morphological class of the core and modifying terms (the head and its dependent), the structure of the simplified monomials varies from the most evidently expressed $A d j .+N$ pattern (Group 1 ) to the $N+N$ pattern (Group 2). According to their syntactic relations, the Ukrainian simplified monomials in Group 1 are characterized by agreement as opposed to the Ukrainian monomials in A\&A from Group 2, for which government is used in majority of cases. What is common with the simplified monomials from Groups 1 and 2 in Ukrainian for A\&A is the number of the core and/or modifying term in the simplified monomial structure, which may be either singular or plural as the set monomial in the terminology. These are just a few findings presented here as it is work in progress and a lot more leads ahead.

6. Chaika, O. (2020). Monomials as Set Term Clusters in Terminologies. International Journal of Philology, Vol. 11(3), Kyiv, «MILENIUM», pp. 9699.

7. Chernovaty, L., Karaban, V. (2005). Dictum Factum Intermediate. Practical English Course. Vinnytsia, Nova Knyha. 355 p.

8. Gumanová, G. (2016). An Analysis of Term-Formation Processes as Employed in English and Slovak Versions of the EU Texts in the Concept of Equivalence (A Case Study). https://www.researchgate.net/publication/31338 4066.

9. Kowalski, G. (2011). Document and Term Clustering. In: Information Retrieval Architecture and Algorithms. Springer, Boston, MA. https://doi.org/10.1007/978-1-4419-77168_6

10. Malkiel, Yakov (1968) Essays on Linguistic Themes. University of California Press, 1968. $415 \mathrm{p}$.

11. Rohwer, R., Freitag, D. (2004). Towards Full Automation of Lexicon Construction. Proceedings of the Computational Lexical Semantics Workshop at HLT-NAACL 2004, pp. 9-16. 
https://www.aclweb.org/anthology/W04-2602.pdf

12. Valeontis, K., Mantzari, E. (2006). The Linguistic Dimension of Terminology: Principles and Methods of Term Formation. 1st Athens International Conference on Translation and Interpretation Translation: Between Art and Social Science, 13-14 October 2006. https://www.researchgate.net/publication/2530249 44.

13. International Audit and Assurance Standards, Volume I published by the IAASB International Audit and Assurance Standards Board. = IAASB as referred to in the publication.

\section{СТРУКТУРА СПРОЩЕНИХ МОНОМІВ (МОНОМІАЛІВ) В УКРАЇНСЬКІЙ МОВІ ОБЛІКУ Й АУДИту \\ О. І. Чайка}

Анотація. У статmі йдеться про будову спрощених мономів в українській фаховій мові для обліку й аудиту. Робота тісно пов'язується з раніше запропонованою ідеєю можливості використовувати терміни «моном» / «мономіал» $і$ «поліном» / «поліміал» як замінники терміна в лінгвістиці у випадках, коли йдеться про структуру, семантику й фуункціонування термінологічних одиниць у межах мовних термінологій. Терміну «моном» («мономіал») характерні такі ознаки. По-перше, пропонується, що моном стає на заміну "терміна» у мовній системі вузькоспеціалізованих термінів (які є природними лише для однієї галузі знань). По-друге, моном може виражатися або однокомпонентним терміном, або двокомпонентним, або трикомпонентним і багатокомпонентним терміном - у відповідності до вимог відповідної термінології. За складністю мономної будови, мономи поділяються на прості (однокомпонентні терміни), спрощені (двокомпонентні терміни), складені та складні. Два останні складаються із стрижневого терміна та залежних термінів, з одного боку, а з іншого, складний моном характеризується додатково синтаксичним підпорядкуванням залежних термінів стрижневому. Основий фокус роботи зосереджується на спрощених мономах, у будову яких входять два смислових терміна, звідси і назва, на відміну від однокомпонентних мономів, простих за своєю природою (способами термінотворення). Матеріалом дослідження слугували приклади мономів із «Міжнародних стандартів контролю якості, аудиту, огляду, іншого надання впевненості та супутніх послуг» у перекладі українською мовою (офіційне формулювання публікації, за Аудиторською палатою України). Українські мономи в галузі аудиту та бухгалтерського обліку демонструють чітке розмежування між двома основними групами їх утворення та будови. Одна група включає складені іменники, за ознакою морфологічного класу термінів у будові монома. Інша група спрощених мономів українською мовою для аудиту та бухгалтерського обліку вдвічі перевищує кількість попередніх $i$ представлена типовим морфологічним зразком adj. + n у більшості досліджуваних випадків.

Ключові слова: моном (мономіал), поліном, спрощений моном (мономіал), монотерм, бітермін, фрахова мова, термінологія, українська мова для аудиту й [бухгалтерського] обліку. 